\title{
Serum CA125 Measurement
}

National Cancer Institute

\section{Source}

National Cancer Institute. Serum CA125 Measurement. NCI Thesaurus. Code C141277.

The determination of the amount of cancer antigen 125 present in a blood serum sample. 